\title{
De-Europeanising or disengaging? EU environmental policy and Brexit
}

\section{Charlotte Burns, Viviane Gravey, Andrew Jordan \& Anthony Zito}

To cite this article: Charlotte Burns, Viviane Gravey, Andrew Jordan \& Anthony Zito (2019) DeEuropeanising or disengaging? EU environmental policy and Brexit, Environmental Politics, 28:2, 271-292, DOI: 10.1080/09644016.2019.1549774

To link to this article: https://doi.org/10.1080/09644016.2019.1549774
(c) 2019 The Author(s). Published by Informa UK Limited, trading as Taylor \& Francis Group.

曲 Published online: 17 Jan 2019.

\section{Submit your article to this journal $\pi$}

\section{Џll Article views: 145}

View Crossmark data $₫$

Citing articles: 1 View citing articles 지 


\title{
De-Europeanising or disengaging? EU environmental policy and Brexit
}

\author{
Charlotte Burns (10), Viviane Gravey $\mathbb{1}^{\mathrm{b}}$, Andrew Jordan $\mathbb{0}^{\mathrm{c}}$ \\ and Anthony Zito $\mathbb{1}^{\mathrm{d}}$
}

aDepartment of Politics, University of Sheffield, UK; 'b School of History, Anthropology, Philosophy and Politics, Queen's University Belfast, UK; 'School of Environmental Sciences, University of East Anglia, UK; 'School of Geography, Politics and Sociology, Newcastle University, UK

\begin{abstract}
The European Union (EU) has had a profound effect upon its members' environmental policy. Even in the United Kingdom (UK), the EU's most recalcitrant member state (historically labeled the 'Dirty man of Europe'), environmental policy has been Europeanised. As the UK moves to the EU's exit door it is timely to assess the utility of Europeanisation for understanding policy dynamics in the UK. Drawing upon interviews and extensive engagement with stakeholders, this article analyses the potential impact of Brexit upon environmental policy and politics. The analytical toolkit offered by deEuropeanisation is developed to identify the factors that drive and inhibit deEuropeanisation processes, thereby providing insights that may be applicable in other settings. Disengagement and policy stagnation are presented as more likely environmental outcomes of Brexit, with capacity emerging as a central explanatory variable.
\end{abstract}

KEYWORDS Brexit; capacity; de-Europeanisation; European Union environmental policy; United Kingdom; policy dismantling

\section{Introduction}

Until recently, scholars have assumed that Europeanisation and the development of the European Union's (EU's) environmental acquis communautaire were largely top down, uni-directional, expansionary and positive for environmental outcomes. The conglomerate of crises (Falkner 2016) that has recently beset the EU has challenged these assumptions (Zito et al. 2019). Since the publication of this journal's 1992 Special Issue on the EU and environmental policy (Judge 1992), academics have depicted the EU as a positive influence on United Kingdom (UK) environmental policy, which they typically describe as being Europeanised (Lowe and Ward 1998; Jordan $2002,2004)$. The UK has downloaded numerous pieces of legislation ${ }^{1}$ and the EU has become part of the daily business of UK environmental 
stakeholders and policy-makers. The UK's anticipated exit from the EU ('Brexit') consequently poses important analytical and empirical challenges to the literatures on Europeanisation and EU and UK environmental policy.

The concepts of dismantling (Gravey and Jordan 2016; Steinebach and Knill 2017) and de-Europeanisation (Copeland 2016) are emerging as key analytical tools for understanding the current and likely future trajectory of EU environmental policy. Here, we build upon these terms and the emerging de-Europeanisation literature to offer an original assessment of the likely implications of Brexit for the UK and for our wider understanding of Europeanisation. At the time of writing, Brexit negotiations are ongoing, the final outcome is unknown. Despite this uncertainty and, recognising that Brexit represents an extreme example of possible de-Europeanisation, we contend that Brexit reflects a wider movement to reduce and limit the EU's influence on its Member States. Drawing upon Hogwood and Peters (1982) insight that current and past policies are likely to shape future policies, we argue that, in the short term, Brexit's immediate impact is likely to be limited, but over the longer term a wider divergence between the EU and UK is likely, with the prospect of UK environmental policy stagnating. Our work chimes with the emerging findings of the dismantling literature: we see little evidence that deliberate de-Europeanisation of environmental policy will follow Brexit, but suggest a longer process of disengagement is likely.

The following sections review the state of the art on the Europeanisation of UK environmental policy and then analyse the referendum campaign and its aftermath, to determine the variables likely to shape deEuropeanisation. Our research draws upon a review of primary and secondary documentary sources, interviews with key political actors drawn from different party backgrounds and evidence gathered from eight stakeholder workshops carried out between 2015 and 2018 involving representatives from environmental non-governmental organisations (ENGOs), civil servants and parliamentary officials from across the UK. The workshops operated under Chatham House rules so we report findings without direct attribution to the individuals concerned.

We make three principal contributions. First, theoretically we refine and extend current work on de-Europeanisation and identify key variables shaping the patterns of behaviour from which we can draw analytical generalisations that can be tested in other national and policy settings. Second, we use original interview and extensive stakeholder engagement data to provide robust evidence to underpin our analysis. Third, we offer one of the first and most extensive political analyses of the implications of Brexit for UK and EU environmental policy and politics. We thereby provide comprehensive analysis of one aspect of Brexit and use 
this case to explore and engage with wider, important debates in the public policy and Europeanisation literatures.

\section{Europeanisation, de-Europeanisation and disengagement}

The mushrooming of Europeanisation studies generated a 'bewilderingly large array of definitions' (Jordan and Liefferink 2004, p. 5); here we draw upon those proposed by Radaelli (2004) and Börzel and Risse (2003). Radaelli (2004) suggests that Europeanisation consists of processes of construction, diffusion and institutionalisation of 'formal and informal rules, procedures, policy paradigms, styles, "ways of doing things" and shared beliefs and norms which are first defined and consolidated in the EU policy process and then incorporated in the logic of domestic (national and subnational) discourse, political structures and public policies' (p. 3). Börzel and Risse (2003) use a threefold typology of the EU's impact upon a state's policy, politics and polity. Here 'policy' refers to the broader policy paradigm and specific policy goals and instruments; 'politics' includes the engagement of civil society, business actors, parties and the wider public with Europeanisation processes; and 'polity' centres on relations between levels of government and formal institutional structures, including administrative capacity and accountability, both within the UK and in the EU.

Early Europeanisation studies generally focused upon the EU's impact upon states, and, whilst retrenchment and resistance to the EU have long been part of the analytical debates about Europeanisation there have been relatively few examples of states actively trying to roll back EU policies at the national level. More recently, we have seen emerging debates around dismantling EU policy (Bauer et al. 2012; Jordan et al. 2013; Gravey and Jordan 2016) and studies elaborating the concept of de-Europeanisation (Aydın-Düzgit and Kaliber 2016; Copeland 2016; Raagmaa et al. 2014). Essentially de-Europeanisation amounts to dismantling EU policy at the domestic level, where dismantling means the 'cutting, diminution or removal of existing policy' (Jordan et al. 2013, p. 795). Copeland (2016) suggests that a key analytical component of de-Europeanisation is that it intentional with 'the specific aim to reverse the process of Europeanisation and to prevent future uploading and down-loading in the governance process' (2016, p. 1126). Significantly, he distinguishes de-Europeanisation from disengagement; the latter involves a state retreating from active Europeanisation, maintaining the domestic processes and structures affected by Europeanisation, but not seeking to adapt them further to the EU's influence.

This conceptual distinction is useful in the Brexit context. The act of leaving the EU clearly constitutes an intention to de-Europeanise. However, it does not follow that the UK will actively dismantle the governance processes and policies established as a consequence of EU membership. 
If, as a result of Brexit, the British government chooses to leave the vast majority of EU environmental (or indeed any other) policy in place, then, despite no longer being an EU member, UK policy may be disengaged rather than de-Europeanised. This description would be particularly apt in those policy sectors, such as environment, where the UK is likely to have to align with EU policy in order to trade with the EU 27, even though the opportunity to upload policy will no longer be available. Consequently, our endeavour is partly to determine the likelihood of active and deliberate attempts to reverse the Europeanisation of UK environmental policy, i.e. the active dismantling (Gravey and Jordan 2016) of the environmental acquis within the UK.

Copeland (2016) identifies two conditions shaping the level and extent of de-Europeanisation. First, the degree to which policy is centralised: policy decided by central government involves fewer veto players making it easier to reverse. Second, the level of domestic political support for the policy. Copeland argues that in the case of EU employment policy the levels of public knowledge and active support were limited, which resulted in less contestation when the policy was rolled back. Conversely, where there is a higher level of knowledge and popular support we should expect deEuropeanisation to prove more challenging. Synthesising Copeland's (2016) and Börzel and Risse (2003) work (see Table 1), we anticipate that, where Europeanisation processes have led to limited changes, de-Europeanisation will be easier to achieve; conversely, where Europeanisation has been more deep-seated, de-Europeanisation will be more difficult and hence disengagement more likely.

The following section provides a succinct review of the state of the art on the Europeanisation of UK environmental policy. We then explore the referendum campaign and its immediate aftermath to determine the likelihood of de-Europeanisation, and the patterns that may emerge in the light of our expectations.

\section{Europeanising the UK's environment}

Prior to the UK referendum there had been relatively few up-to-date academic analyses of UK environmental policy. Reviews of specific policies were produced, especially on climate change and energy policy following the UK's pioneering Climate Change Act (Carter and Jacobs 2014; Lorenzoni and Benson 2014; Lockwood 2013), but analyses of broader UKEU policy dynamics were notable by their absence, which reflected the relative stability of UK environmental policy and the academic consensus that UK environmental policy had been Europeanised (Lowe and Ward 1998; Jordan 2002). Below we review what this meant in relation to policy, politics and polity. 


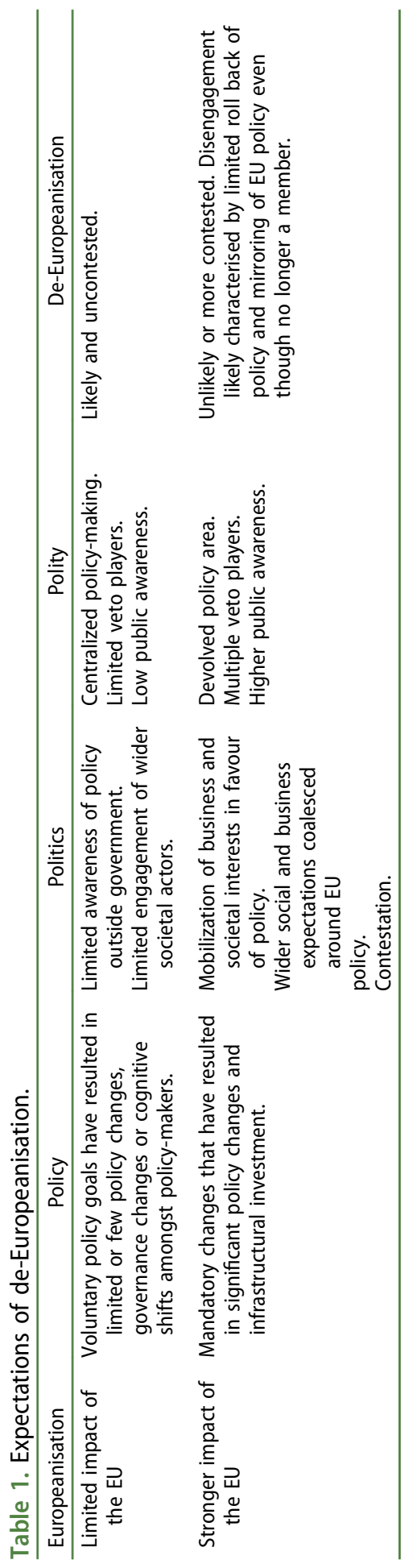




\section{Policy}

When the UK joined the EU, UK environmental policy making was ad hoc, reactive, and based upon end-of-pipe solutions (Weale et al. 2000, p. 177). Implementation was patchy, favouring a voluntarist approach that relied upon negotiated consent (Lowe and Ward 1998). This policy style was completely at odds with that favoured by the 'green pioneers' (Denmark, the Netherlands and Germany). These states uploaded domestic models to the European level to minimise their downstream implementation costs (Börzel 2002). Thus, the UK persistently found itself having to implement policies designed for other political systems, most often the more inflexible and legalistic German policymaking system (Wurzel 2006). Consequently, EU membership prompted the development in the UK of a more organised, proactive and integrated environmental policy based upon clear and enforceable targets. However, Jordan (2004) suggests that the extent to which the UK environmental policy paradigm shifted is debateable: in some areas, such as water and air, the EU's impact was more extensive than in others, such as land use planning (Wurzel 2006; Cowell and Owens 2016). Hence, the patterns of Europeanisation across the sector varied.

Nevertheless, over time UK policymakers gradually learnt to 'think European' (Jordan 2003, p. 263), as the government and civil servants sought to adapt to the challenge of policymaking in Brussels. From the 1990s onwards, UK actors sought, in certain policy areas, to set the EU's agenda, both by leading and blocking action. For example, the UK blocked major Commission proposals on environmental taxation and soil protection. In the early 1990s, the UK tried to shape the EU policy agenda in a range of ways. It sought to advance its voluntary policy approach, but met with limited success. UK attempts to shape the types of instruments used by the EU, by advancing the use of more market-based approaches such as environmental auditing and eco-labels, and integrated pollution control were better received (Jordan 2002; Haigh 2015). The UK also started to push for greater attention to be paid to the regulatory burdens (or 'red tape') of environmental action. This agenda became central to UK European policy, from Labour, which put 'better regulation' at the heart of its 2005 Presidency of the Council of the EU (House of Lords 2005), to the Conservatives. 'Cutting EU red tape' was also a core part of the 2010-2015 coalition government's EU strategy (Business Taskforce 2013) and it became one of David Cameron's four negotiation objectives when he set out to reform the EU Treaties prior to the 2016 Brexit referendum (Cameron 2015).

\section{Politics}

EU membership has shaped the strategies of various domestic actors (including non-government organisations (NGOs), businesses and to a lesser extent 
political parties). ENGOs have learned how to use EU governance structures to hold the UK government to account (Haigh 2015). For example, they contested UK attempts to minimise compliance costs of the Bathing Water Directive by designating only 27 bathing areas (Jordan 1997). The EU also provided funding for ENGOs and provided a platform for pan-European collaboration (Berny 2016). UK-based ENGOs have been central to the creation of EUlevel ENGOs, which have influenced European policymaking (Berny 2008). Moreover, UK ENGOs and think-tanks have directly shaped EU policymaking, notably on integrated pollution control (Haigh 2015) and agricultural reform (Fouilleux and Ansaloni 2016).

UK businesses have also engaged with the EU's environment agenda. The desire to reduce costs and uncertainty for businesses has been a key driver of EU environmental policy. The Stern Review (Stern 2006), which made the case for ambitious climate policy, attracted wide business support in favour of EU climate regulations (Carter and Jacobs 2014). However, some companies and types of business continue to rail against Brussels 'red tape'. Developers have consistently identified the habitats and birds directives as imposing costs upon them. Farmers have levelled similar criticisms at EU pesticide regulations (National Farmers' Union 2017).

For the first 30 years of the UK's EU membership, the two main parties did not directly compete over the environment (Carter 2006). However, in the mid-2000s, the Conservative party sought to rebrand itself by embracing the environment as a way to 'detoxify' its image (Carter 2009). Labour, the Liberal Democrats and the Conservatives competed fiercely over climate change policies, leading to the adoption of the 2008 Climate Change Act (Carter and Jacobs 2014), which eventually proved divisive within the Conservative Party. The government's efforts to meet its EU renewables targets prompted internal opposition, particularly to onshore wind farms and green duties on energy bills (Carter and Clements 2015). Similarly, Conservative Chancellor George Osborne, identified the EU Habitats Directive as 'placing ridiculous costs on businesses' (Osborne 2011). Growing climate scepticism and opposition on the right to environmental regulations connected directly with and drew much strength from the powerful anti-EU lobby within the party.

Of UK political parties, the Greens have most obviously benefitted from EU membership. Since the introduction of proportional representation for European elections, the Greens have consistently secured representation of at least two Members of the European Parliament (MEPs). They have used their MEPs to build their domestic profile and secure further support (Bomberg and Carter 2006). For example, party co-chair Caroline Lucas used her stint as an MEP as a springboard to become a Westminster MP. 


\section{Polity}

Whilst the EU has profoundly influenced the type of environmental policies implemented in the UK, the use of directives, 'orientated towards the ends to be achieved, rather than the means of achievement' (Bulmer and Jordan 2016, p. 9), has limited the EU's impact on domestic government. Rather, EU membership triggered a long and slow transformation within UK government to enable it to deal with its European neighbours (Burch and Bulmer 2005). Hence, whilst there has been reorganisation of government structures within the UK, particularly for environmental policy, ${ }^{2}$ these changes have largely been driven by domestic concerns and it is challenging to disentangle the effect of Europeanisation from other processes (Bulmer and Jordan 2016; Jordan 2002). The most significant changes have occurred at the intersection of polity and policy where the act of pooling sovereignty has led to a pooling of capacity across EU states. Thus, several EU agencies are responsible for giving advice and administering EU rules, which means that EU states do not have to maintain equivalent structures at the domestic level.

The EU has also provided governance architecture to support policy development and implementation, including networks to exchange best practice such as the EU Network for the Implementation and Enforcement of Environmental Law (IMPEL). For example, the UK government is obliged to report on a whole range of policy activities, with the data made publicly available, as in the case of bathing waters. Furthermore, if the government fails to report regularly or to implement EU policies it can be held to account in national courts and see itself pursued at EU level. EU membership has consequently had a profound impact both upon the substantive norms underpinning environmental policy (what the rules are) and upon institutional norms (who enacts policy) (Roger 2016).

Furthermore, whilst EU membership has not profoundly affected government structures, the UK's devolution settlements have led to changes that EU membership has augmented. Currently, the EU sets minimum levels for environmental policy. Member states can diverge from them (under Article 193 of the Treaty on the Functioning of the EU-the socalled environmental guarantee), but only by pursuing higher environmental standards. The combined effects of Article 193 and the devolution settlements have allowed policy divergence to emerge within the UK where policies go further than the EU prescribed minimum (Hunt et al. 2016; Reid 2016). Consequently, Wales and Scotland have adopted more ambitious climate change policies than England (Royles and McEwen 2015); Wales, Scotland and Northern Ireland, have banned the cultivation of GMOs, but England has not (Coghlan 2015). 


\section{The referendum campaign and its aftermath:} de-Europeanisation?

Overall we can see that policy, politics and polity have all been Europeanised, although the patterns and depth of that Europeanisation has varied. Below we review evidence from the referendum campaign and its aftermath (using our three categories) to determine the extent to which a demand for deEuropeanisation has existed, and, if so, the factors shaping it.

\section{De-Europeanised policy?}

A vocal lobby has emerged in the UK that favours rolling back EU legislation; Brexit has been presented as a golden opportunity to remove legislation that this group views as problematic, most notably the habitats and birds directives, which have become the bête verte of the conservative right (Environment Analyst 2016). Indeed, a key theme emerging from our stakeholder events was a deep fear that these two directives will face amendment or be removed after Brexit. Wildlife NGOs view UK legislation as offering weaker protections than its EU equivalent. ${ }^{3}$ Michael Gove, appointed Secretary of State for the Environment, Food and Rural Affairs in Summer 2017, committed himself to the pursuit of a green Brexit, stating that there would be no weakening of standards post-Brexit (Gove 2017). However, the Department for International Trade will lead negotiations to secure post-Brexit trade deals. A clear fear that stakeholders expressed was that future trade deals would see products coming into the UK subjected to lower standards, leading to downward pressure upon domestic standards. Moreover, several interviewees, whilst welcoming a committed environment minister, were concerned that $\mathrm{Mr}$ Gove would not remain long in post, potentially leaving the environment vulnerable to the appointment of a less environmentally committed minister (Interviews 11/08/17; 07/09/17; 25/09/17). These comments flag a key concern that the previously stable policy regime emanating from Brussels could, when repatriated, be subject to domestic political variation (Interview 07/09/17). Stakeholders also expressed concern that the UK faces a reassertion of the voluntarist, flexible policy style preferred prior to the UK's EU membership, and still apparent in some areas such as planning (Cowell and Owens 2016).

To pave the way to Brexit the UK parliament has adopted an EU Withdrawal Act (EUWA), which has also led to concerns about environmental policy dismantling. When the UK joined the EU, it adopted the 1972 European Communities Act (ECA) to give effect to its obligations as an EU member state. In the UK, national implementing measures give directives legal effect; however, article 2(2) of the ECA gives regulations effect without any specific implementing legislation. Consequently, when 
the ECA ceases to apply, national measures adopted to give effect to directives would remain in place but regulations would cease to apply, potentially creating numerous regulatory gaps. To address this problem, the EUWA retains all existing EU rules and regulations in national law to prevent legal uncertainty in the short term.

This approach contains an assumption that at some point the vast array of laws adopted to give effect to EU obligations will be reviewed, and decisions made about whether they should be maintained or scrapped, raising the risk of policy dismantling. The Department for Environment, Food and Rural Affairs (Defra) is the second most heavily affected department by the EUWA, with the EU affecting approximately $80 \%$ of its work (National Audit Office 2017). There is an expectation that Defra will need to bring forward 95 statutory instruments to implement the EUWA, and two new domestic bills on agriculture and fisheries to replace the Common Agriculture and Common Fisheries policies (National Audit Office 2017). The scale of work Defra and other departments face is likely to mitigate against an immediate and widespread roll back of EU environmental policy. Equally, however, there is a risk that the Withdrawal Act has failed to sufficiently address regulatory gaps, or will leave unanticipated gaps within UK environmental governance. The fact that the EUWA, as originally framed, failed to copy over environmental principles from the EU treaties into UK law, such as the protection, precautionary and polluter pays principles, was identified by ENGOs as problematic. They campaigned vigorously on the issue leading the government to bring forward a consultation on environmental governance and principles (DEFRA 2018a) and the House of Commons adopted an amendment to the EUWA requiring the government to bring forward a Bill enshrining environmental principles (House of Commons 2018). However, the amendment to the EUWA does not demand the pursuit of a higher level of environmental protection, as required by the EU Treaties (see House of Commons 2018).

Moreover, the EUWA affords a good deal of discretion to government ministers to change laws without proper parliamentary scrutiny. One interviewee expressed concern that ministers would not be able to avoid the temptation to change laws and could do so without scrutiny and in ways that might appear minor but could be significant in scope, by, for example, removing all future reporting requirements from EU legislation being copied over (Interview 7/09/17).

Finally, it is worth noting that Brexit has implications for EU-level policy dynamics. The UK has been a strong advocate of higher ambition in areas such as climate change in the EU Council; Brexit may weaken the EU's ability to promote higher international standards (Interviews 07/09/17; 25/ 09/17). Conversely, the UK has also led calls to cut EU regulatory burdens; Brexit will test whether better regulation is merely an 'Anglo-Saxon obsession' (House of Lords 2005, p. 21). Brexit also constitutes one more policy 
challenge that the EU must face in its crowded policy agenda, raising the prospect that the environment will be pushed further down the list of policy priorities (Burns and Tobin 2016; Slominski 2016).

\section{De-Europeanised politics?}

ENGOs responded rapidly and robustly to Brexit by launching a Greener UK campaign and mobilising to call for a New Nature Protection Act to preserve and develop environmental protections (Greener UK 2017). When appointed, Michael Gove moved quickly to secure ENGO support by meeting with key personnel (Interview 31/08/17). However, it remains to be seen whether ENGOs will be able to maintain a high level of issue salience across such a wide range of issues. In the past, British ENGOs have also played a substantial role in supporting ENGOs in other EU member states (Hofmann 2019). Although this role may not completely disappear after Brexit, UK ENGOs may well be tempted to focus their energies on holding the line in the UK. Here the level of public awareness and the ability of ENGOs to mobilise the public will be central. Evidence suggests that the British continue to care about the environment. Prior to the referendum, $47 \%$ of the British public claimed to support more EU integration in environment and climate policy (Vasilopoulou 2015), and 46\% supported a call for UK environmental protections to be stronger post-Brexit (YouGov 2016).

Of the main political parties, key Labour voices have emerged on the environment, most notably Sadiq Khan, the Mayor of London. Khan (2017) has sought to exploit London's poor air quality as a political issue. Labour garnered support from younger voters (60\% of 18-24-year olds voted Labour) in the 2017 election (Holder et al. 2017); one strategy it may employ to win power is to use the environment agenda to create space between the Conservative and Labour parties. Commentators have suggested that the need to attract younger voters partly explains why the Conservative government published its long awaited 25-year environment plan (25YEP) in January 2018 (Steffani and Cooper 2018). Hence, whilst the environment did not feature much in the referendum, Brexit has seen a growing politicisation over environmental issues.

Within industry, the picture is even less clear. The Confederation of British Industry (CBI) has generally supported EU membership and the EU's green growth agenda. Concerns exist about the implications of Brexit for different UK economic sectors-leading to calls for a 'whole economy' approach (CBI 2016). Business has also expressed concern about uncertainty, especially over energy and product regulations (House of Commons 2017a). Sectors, such as chemical production, that are heavily reliant on EU rules to trade with the Single Market have been especially vocal about ensuring regulatory certainty. The UK government has indicated its desire 
to establish its own set of procedures and a new, national chemicals agency (DEFRA 2018b). However, MPs have emphasised that, to ensure frictionless trade into the Single Market, the pragmatic option is to abide by current EU product standards (even though the UK would have no role in determining them) and to accept EU regulatory oversight (House of Commons 2017b).

\section{De-Europeanised polity?}

The chemicals example highlights a much bigger issue: to what extent will actors within the polity still be able to draw upon the knowledge that has been pooled with EU partners? This question goes well beyond the chemicals sector to include a much larger number of trade substances (e.g. genetically modified organisms, foodstuffs, plastic waste). The expected loss of access to expertise combined with the civil service's diminished size, despite recent appointments, raises the risk that, whilst immediate wide-scale policy dismantling may not occur, significant national policy innovation is also unlikely.

Ironically, given the EU's limited direct impact upon how the UK government operates, Brexit is raising significant constitutional challenges to the existing relationship between different government tiers within the UK. The UK Government announced that the Withdrawal Act would provide delegated statutory powers to 'enable Ministers to adjust the acquis to fit the outcome of the negotiation' (Caird 2016, p. 24). This highlights the issue of veto players and the balance of power between the executive and legislative branches, and between Westminster and the devolved nations. It is unclear who will be responsible for sorting through the hastily carried over swathe of EU legislation. It remains to be seen whether ministers will be able to dismantle environmental policy through administrative channels, without parliamentary scrutiny (House of Lords 2017). There is also ongoing uncertainty about how UK-wide agreements on future environmental policy will be designed. The wording of the Withdrawal Act caused controversy between the UK government and the devolved administrations as the UK government suggested it would decide which policies would be devolved post-Brexit, which the Welsh and Scottish governments characterised as a power grab. In 2018 the Scottish government refused its consent to the EUWA and started preparing rival ('continuity') legislation (Scottish Government 2018). A major constitutional crisis is brewing between the UK polities over who has the right to decide on common UK environmental frameworks post-Brexit (Petetin 2018).

These polity-related issues may interact with politics as the veto players in the devolved nations form alliances with other actors to contest deEuropeanisation of environmental policy. One possible outcome is 
increasingly divergent policy patterns across the UK regions (once common EU rules are removed) (Reid 2015) and thus more varied patterns of (de) Europeanisation. A key limitation that the devolved nations face in pursuing different policy goals from the UK is their relatively weak capacity and expertise. Thus the UK faces the challenge of disentangling itself from the EU acquis and developing new patterns to share competence and develop policy across the UK nations, all under a severely constrained administrative capacity at every governance level. The government announced cuts to Defra's budget of 15\% in real terms between 2015 and 2020; the Royal Society for the Protection of Birds and the Wildlife Trusts argue that Defra has borne some of the biggest cuts across the whole of Whitehall (Howard 2015). Whilst the government has since spent $£ 2$ billion in getting Whitehall ready for Brexit, extra funding for Defra has only partially offset previous and planned cuts, with staffing back to its 2011 level (Owen et al. 2018). Local government, which is often tasked with implementing environmental policy on the ground, has faced an equivalent level of budgetary restriction, with no extra Brexit preparation funding; these actors have hotly contested the availability of council policy instruments and budgetary resources, for instance to implement the 2017 national plan to improve town and city air quality (Merrick 2017).

Concerning governance capacity more broadly, a key risk of the EUWA is that laws pasted into the UK statute book may remain in place with no governance or legal infrastructure to support them. For example, the Water Framework Directive has reporting requirements obliging states to send regular updates on how they implement the directive. Such obligations may no longer apply to the UK; currently no detailed plans exist to replace these reporting requirements at the domestic level. Additionally, actors can currently pursue the government through the Courts for failing to implement EU legislation and ultimately in front of the Court of Justice of the European Union (CJEU). Thus, Client Earth successfully took the UK government to court for failing to implement air quality laws (Client Earth 2017). Once the UK leaves the EU that ability to rely upon the accountability and legal infrastructure enshrined by the EU to enforce legislation will no longer apply (House of Lords 2016). The government's 25YEP committed to bringing forward a new environmental watchdog for England to address these concerns, but its scope and power, and relationship to equivalent bodies in the devolved nations remain uncertain (DEFRA 2018b).

\section{De-Europeanisation after Brexit?}

Do these post-referendum discussions imply that the UK is moving towards a period of de-Europeanisation? Two broader points are worth making upfront. First, disentangling the UK from the EU will be challenging; if there 
is de-Europeanisation, it is unlikely to be rapid. One obvious exception would be if the UK fails to secure a deal or a suitable transition period, which could have significant effects in those policy areas where the UK relies upon EU expertise, and is unlikely to be able to put in place equivalent structures. A key example is the nuclear energy sector where, if the UK fails to reach an agreement with the EU, the UK may find itself struggling to source medical isotopes and nuclear fuel, notwithstanding the fact that the House of Commons has adopted a nuclear safeguards bill (Institute for Government 2018). Second, the patterns of de-Europeanisation are likely to be as 'differentiated' as the patterns of Europeanisation (Jordan and Liefferink 2004), which means we need to pay careful attention to changes within and the interactions between the policy, politics and polity dimensions.

The impact of Brexit and de-Europeanisation are consequently likely to vary: unpicking the policy patchwork of EU membership (Héritier 1996) could be complex and uneven. Copeland (2016) notes that the fact that employment policy was centralised facilitated de-Europeanisation. Environmental policy, with its messier, devolved structure will prove more resistant. In policy areas where Europeanisation is most profound, divergence may only emerge over the longer term. Given the EU's ability to impose its product standards on nonmember states (i.e. all chemicals imported into the EU must be compliant with the regulation on Registration, Evaluation and Authorisation of Chemicals $[\mathrm{REACH}])$, de-Europeanisation will be challenging. At the paradigmatic level, given the relative resilience of the UK's preferred policy approach (Jordan 2002), de-Europeanisation in the form of a reassertion of the UK style of policy at the domestic level is likely

Within the politics sphere, Brexit will shape various organisations, perhaps forcing a more introspective focus. Businesses have started mobilising within the UK, and expressed concern especially about the impact on investment and productivity (Cox et al. 2017, Savage 2017). There is scope for ongoing politicisation of environmental politics: what has been a technical matter decided in Brussels may become part of domestic political debate and contestation. Clear space between the parties emerged on the environment in the 2017 General Election (Laville et al. 2017). An on-going attempt to stigmatise 'EU green tape' occurred in the run up to the referendum campaign (Interview 31/08/17). If this campaigning continues, greater de-Europeanisation may occur. Here we depart from Copeland who assumes that wider public engagement and contestation act as a brake on de-Europeanisation; it may also be a driver.

Finally, on polity, the EU has had limited effects but the interaction between devolution and the EU's environmental guarantee has opened up the possibility of a differentiated de-Europeanisation and divergence across the composite states of the UK.

Overall, the future patterns of environmental governance look complex; ironically, the interaction between polity (where Europeanisation was most 
limited) and policy may make de-Europeanisation harder to achieve. Moreover, UK-level capacity (or rather its absence) is likely to be a central condition determining whether we see de-Europeanisation or disengagement in the environmental policy sector. Whilst the act of leaving the EU will be deliberate, the future patterns of policy change may end up being the result of disengagement rather than deliberate de-Europeanisation. Future studies may wish to distinguish between disengagement occurring where deEuropeanisation has been tried and has failed, and disengagement due to lack of capacity, energy, or political will. We suggest extending the deEuropeanisation typology to encompass failed de-Europeanisation, as distinct from passive de-Europeanisation (or qua Copeland disengagement).

Returning to Table 1, our initial expectations are being borne out-albeit with some additional consideration of the role of capacity. A limited capacity to roll back policy or to innovate is likely in the UK: we certainly see little appetite for or prospect of an environmental policy renaissance in the immediate future, with all that implies for environmental outcomes (Simkins 2017). Hence a discussion of capacity is essential when discussing the scope for deEuropeanisation. Building upon Table 1 and our analysis, we suggest a typology of disengagement that distinguishes between passive and failed deEuropeanisation and identifies capacity as a central variable (Table 2).

\section{Conclusions}

Brexit is the latest in a series of crises to beset the EU at a time when environmental policy was already struggling and in some respects, in retreat. As the UK is one of the EU's most Euro-sceptic states, it would be easy to assume that Brexit will herald wide-scale environmental policy dismantling at the national level. We contend, however, that, if and when the UK leaves the EU, this outcome is unlikely. UK policy has been profoundly Europeanised in ways that will be difficult to disentangle and completely reverse.

Table 2. Brexit as disengagement.

\begin{tabular}{|c|c|c|c|}
\hline Expectation & Policy & Politics & Polity \\
\hline $\begin{array}{l}\text { Disengagement as } \\
\text { passive de- } \\
\text { Europeanisation. }\end{array}$ & $\begin{array}{l}\text { Policy stays in place and } \\
\text { gradually becomes out- } \\
\text { dated. }\end{array}$ & $\begin{array}{l}\text { De-politicization } \\
\text { and identification } \\
\text { of environment } \\
\text { as technical low } \\
\text { politics. } \\
\text { Lack of resources } \\
\text { amongst NGOs. }\end{array}$ & $\begin{array}{l}\text { Lack of state capacity } \\
\text { to review or } \\
\text { retrench policy. }\end{array}$ \\
\hline $\begin{array}{l}\text { Disengagement as failed } \\
\text { de-Europeanisation }\end{array}$ & $\begin{array}{l}\text { Deliberate attempts to de- } \\
\text { Europeanise thwarted- } \\
\text { policy stays as is, } \\
\text { gradually being } \\
\text { undermined via } \\
\text { technical adjustments. }\end{array}$ & $\begin{array}{l}\text { Contestation results } \\
\text { in stalemate. } \\
\text { Brexit fatigue } \\
\text { sets in. }\end{array}$ & $\begin{array}{l}\text { Joint-decision trap- } \\
\text { too many veto } \\
\text { players to move } \\
\text { either way. Policy } \\
\text { stasis follows. }\end{array}$ \\
\hline
\end{tabular}


Our analysis of debates about the future of environmental policy, interviews and stakeholder engagement leads us to expect capacity (or rather its absence) to be a central variable. Lack of capacity means that there will be limited ability to unpick the domestic manifestation of the EU's environmental acquis. Yet significant national policy innovation is also unlikely. This finding is consistent with earlier Europeanisation studies, which identified capacity as a limit upon policy implementation (Börzel 2002). Brexit may, therefore, have a relatively limited impact on policy outputs, but have potentially more significant consequences for policy outcomes, as stasis and passive environmental policy dismantling emerge over the medium to long term. The politics of the environment will be central: the UK's vibrant ENGO sector and deepseated public support for protecting the environment will be crucial in determining the strength of post-Brexit environmental governance arrangements.

What are the implications for the future of EU environmental policy? In the absence of the UK, we may see less EU-level emphasis upon 'regulatory burdens' and the red tape agenda. We may also see other Euro-sceptic and environmentally-sceptic voices emerging to replace the UK, crucially in the area of climate change where the UK generally played an important role. However, our analysis suggests that the EU's impact upon its member states is such that disentangling and unpicking effects of membership is challenging, especially in a devolved polity. Hence, rather than heralding the disintegration of the EU and large-scale de-Europeanisation, Brexit may actually demonstrate the resilience of Europeanisation in face of extraordinary challenges. Returning to Hogwood and Peters (1982), we suggest that, whilst the UK is leaving the EU, there will be extensive and sticky policy residue that even the most committed Brexiteers will find challenging to remove.

\section{Acknowledgements}

We thank three anonymous referees, Sina Leipold and Andrea Lenschow for their detailed criticisms. We also thank participants in the Pisa ECPR workshop, 24-29 April 2016, 'The Future of Environmental Policy in the European Union Workshop', University of Gothenburg, 19-20 January 2017, and the panel at the 3rd International Conference on Public Policy (ICPP), Singapore, 28-30 June 2017. We are grateful to the ESRC for funding the research underpinning this work through its 'UK in a Changing Europe Initiative' (a Commissioning Grant, and Brexit Priority Grant ES/R00028X/1).

\section{Notes}

1. See https://www.cieem.net/data/files/Resource_Library/Policy/Policy_work/ CIEEM_EU_Directive_Summaries.pdf for detail.

2. In 1997 the UK Labour government created the Department of Environment Transport and the Regions, which the Department for Environment Food and 
Rural Affairs (Defra) replaced in 2001. It established the Department for Energy and Climate Change in 2008, which was dismantled and its functions redistributed by the Conservative government in 2016.

3. Wilkinson, Friends of the Earth Referendum Roadshow, Leeds, 13 May 2016.

\section{Disclosure statement}

No potential conflict of interest was reported by the authors.

\section{Funding}

This work was supported by the ESRC [ES/R00028X/1].

\section{ORCID}

Charlotte Burns (D) http://orcid.org/0000-0001-9944-0417

Viviane Gravey (D) http://orcid.org/0000-0002-3846-325X

Andrew Jordan (D) http://orcid.org/0000-0001-7678-1024

Anthony Zito (D) http://orcid.org/0000-0002-2312-4781

\section{References}

Aydın-Düzgit, S. and Kaliber, A., 2016. Encounters with Europe in an era of domestic and international turmoil: is Turkey a de-Europeanising candidate country? South European Society and Politics, 21 (1), 1-14. doi:10.1080/13608746.2016.1155282

Bauer, M.W., et al., 2012. Dismantling public policy: preferences, strategies, and effects. In: M.W. Bauer, C. Green-Pedersen, A. Héritier, and A. Jordan, eds. Dismantling public policy. Oxford: Oxford University Press, 203-226.

Berny, N., 2008. Le lobbying des ONG internationales d'environnement à Bruxelles. Revue francaise de science politique, 58 (1), 97-121. doi:10.3917/rfsp.581.0097

Berny, N., 2016. Environmental groups. In: C. Burns et al. The EU Referendum and the UK environment: an expert review, 112-124. Available from: http://environ menteuref.blogspot.co.uk/p/the-report.html [Accessed 1 January 2017].

Bomberg, E. and Carter, N., 2006. The greens in Brussels: shaping or shaped? European Journal of Political Research, 45 (S1), 99-125. doi:10.1111/j.14756765.2006.00651.x

Börzel, T.A., 2002. Pace-setting, foot-dragging, and fence-sitting: member state responses to Europeanization. Journal of Common Market Studies, 40 (2), 193-214. doi:10.1111/1468-5965.00351

Börzel, T.A. and Risse, T., 2003. Conceptualizing the domestic impact of Europe. In: K. Featherstone and C. Radaelli, eds. The politics of Europeanization. Oxford: Oxford University Press, 57-80.

Bulmer, S. and Jordan, A., 2016. National government. In: C. Burns et al. The EU Referendum and the UK environment: an expert review, 79-89. Available from: http://environmenteuref.blogspot.co.uk/ [Accessed 1 January 2017]. 
Burch, M. and Bulmer, S., 2005. The Europeanization of UK government: from quiet revolution to explicit step-change? Public Administration, 83 (4), 861-890. doi:10.1111/j.0033-3298.2005.00481.x

Burns, C. and Tobin, P., 2016. The impact of the economic crisis on European Union environmental policy. Journal of Common Market Studies, 54 (6), 1485-1494. doi: $10.1111 / \mathrm{jcms} .12396$

Business Taskforce, 2013. Cut EU red tape - Report from the business taskforce, 1-60. https://www.gov.uk/government/publications/cut-eu-red-tape-report-from -the-business-taskforce [Accessed 262 2018].

Caird, J., 2016. Legislating for Brexit : the great repeal bill. Briefing Paper House of Commons Library, 7793, 57.

Cameron, D., 2015. A new settlement for the United Kingdom in a reformed European Union. Communication to Donald Tusk. Available from: https://www. gov.uk/government/uploads/system/uploads/attachment_data/file/475679/ Donald_Tusk_letter.pdf [Accessed 27 July 2017].

Carter, N., 2006. Party politicization of the environment in Britain. Party Politics, 12 (6), 747-767. doi:10.1177/1354068806068599

Carter, N., 2009. Vote blue, go green? Cameron's conservatives and the environment. The Political Quarterly, 80 (2), 233-242. doi:10.1111/poqu.2009.80. issue-2

Carter, N. and Clements, B., 2015. From 'Greenest government ever' to 'Get rid of all the green crap': David Cameron, the conservatives and the environment. British Politics, 10 (2), 204-225. doi:10.1057/bp.2015.16

Carter, N. and Jacobs, M., 2014. Explaining radical policy change: the case of climate change and energy policy under the British labour government 2006-2010. Public Administration, 92 (1), 125-141. doi:10.1111/padm.12046

CBI, 2016. Making a success of Brexit: a whole-economy view of the UK-EU negotiations. Available from: http://www.cbi.org.uk/insight-and-analysis/mak ing-a-success-of-brexit/ [Accessed 18 June 2017].

Client Earth, 2017. High court judgment on air pollution a 'shot across the bows' of government. Available from: https://www.clientearth.org/high-court-judgmentair-pollution-shot-across-bows-government/ [Accessed 19 July 2017].

Coghlan, A., 2015. More than half of EU officially bans genetically modified crops. New Scientist, 5 October 2017.

Copeland, P., 2016. Europeanization and de-Europeanization in UK employment policy: changing governments and shifting agendas. Public Administration, 94 (4), 1124-1139. doi:10.1111/padm.2016.94.issue-4

Cowell, R. and Owens, S., 2016. Land use planning. In: C. Burns et al. The EU Referendum and the UK environment: an expert review, 57-67. Available from: http://environmenteuref.blogspot.co.uk/. [Accessed 1 January 2017].

Cox, J., Chu, B., and Rodinova, Z., 2017. Cost of Brexit: the impact on business and the economy so far. The Independent. 21 April.

DEFRA, May 2018a. Environmental principles and governance after the United Kingdom leaves the European Union, consultation on environmental principles and accountability for the environment. Available from: http://www.gov.uk/gov ernment/publications [Accessed 22 June 2018].

DEFRA, January 2018b. A green future: our 25 year plan to improve the environment. Available from: https://www.gov.uk/government/publications/25year-environment-plan [Accessed 11 January 2018]. 
Environment Analyst, 2016. Fears grow for nature directives post-Brexit. Available from: https://environment-analyst.com/48344/fears-grow-for-nature-directivesin-the-uk-post-brexit [Accessed 18 June 2017].

Falkner, G., 2016. The EU's current crisis and its policy effects: research design and comparative findings. Journal of European Integration, 38 (3), 219-235. doi:10.1080/07036337.2016.1140154

Fouilleux, E. and Ansaloni, M., 2016. The common agricultural policy. In: M. Cini and N. Pérez-Solórzano Borragán, eds. European Union politics. Oxford: Oxford University Press, 308-322.

Gove, M., 2017. The unfrozen moment - delivering a green Brexit, Speech. Available from: https://www.gov.uk/government/speeches/the-unfrozen-momentdelivering-a-green-brexit [Accessed 1 Janury 2018].

Gravey, V. and Jordan, A., 2016. Does the European Union have a reverse gear? Policy dismantling in a hyperconsensual polity. Journal of European Public Policy, 23 (8), 1180-1198. doi:10.1080/13501763.2016.1186208

Greener UK, 2017. Greener UK. Available from: http://greeneruk.org/ [Accessed 18 June 2017].

Haigh, N., 2015. EU environmental policy: its journey to centre stage. London: Routledge.

Héritier, A., 1996. The accommodation of diversity in European policy-making and its outcomes: regulatory policy as a patchwork. Journal of European Public Policy, 3 (2), 149-167. doi:10.1080/13501769608407026

Hofmann, A., 2019. Left to interest groups? On the prospects for enforcing environmental law in the European Union. Environmental Politics, 28 (2).

Hogwood, B. and Peters, B.G., 1982. The dynamics of policy change: policy succession. Policy Sciences, 14 (3), 225-245. doi:10.1007/BF00136398

Holder, J., Barr, C., and Kommenda, N., 2017. Young voters, class and turnout: how Britain voted in 2017. The Guardian, 20 June. Available from: https://www. theguardian.com/politics/datablog/ng-interactive/2017/jun/20/young-voters-class -and-turnout-how-britain-voted-in-2017 [Accessed 1 January 2018].

House of Commons, 2017a. The future of the natural environment after the EU Referendum inquiry, Environmental Audit Committee. Available from: https:// publications.parliament.uk/pa/cm201617/cmselect/cmenvaud/599/599.pdf [Accessed 27 July 2017].

House of Commons, 2017b. The future of chemicals regulation after the EU Referendum inquiry, Environmental Audit Committee. Available from: https:// www.publications.parliament.uk/pa/cm201617/cmselect/cmenvaud/912/912.pdf [Accessed 18 June 2017].

House of Commons, 2018. European Union withdrawal bill, commons amendments in lieu, amendments to amendments and reasons. Available from https:// publications.parliament.uk/pa/bills/lbill/2017-2019/0111/18111.pdf\#page $=3$ [Accessed 29 June 2018].

House of Lords, 2005. Ensuring effective regulation in the EU. 9th Report of Session 2005-2006.

House of Lords, 2016. Brexit: environment and climate change inquiry. European Union Committee. 12th Report of Session 2016-17, HL Paper 129. Available from: https:/www.parliament.uk/business/committees/committees-a-z/lords-select/euenergy-environment-subcommittee/inquiries/parliament-2015/brexitenvironment-and-climate-change/[Accessed 1 January 2017].

House of Lords, 2017. The 'great repeal bill' and delegated powers. Constitution Committee, 9th Report of Session 2016-17. HL Paper 123. Available from: https:// 
publications.parliament.uk/pa/ld201617/ldselect/ldconst/123/12302.htm [Accessed 30 October 2018].

Howard, E., 2015. Defra hit by largest budget cuts of any UK government department, analysis shows. The Guardian, 11 November. Available from: https://www. theguardian.com/environment/2015/nov/11/defra-hit-by-largest-budget-cuts-ofany-uk-government-department-analysis-shows [Accessed 27 July 2017].

Hunt, J., Minto, R., and Woolford, J., 2016. Winners and losers: the EU referendum vote and its consequences for Wales. Journal of Contemporary European Research, 12 (4), 824-834.

Institute for Government, 2018. Explainers: euratom. Available from https://www. instituteforgovernment.org.uk/explainers/euratom [Accessed 29 June 2018].

Jordan, A., 1997. 'Overcoming the divide' between comparative politics and international relations approaches to the EC: what role for 'post-decisional politics'? West European Politics, 20 (4), 43-70. doi:10.1080/01402389708425217

Jordan, A., 2002. The Europeanisation of British environmental policy, a departmental perspective. Basingstoke: Palgrave Macmillan.

Jordan, A., 2003. The Europeanisation of national government and policy: a departmental perspective. British Journal of Political Science, 33 (2), 261-282. doi:10.1017/S0007123403000115

Jordan, A., 2004. The United Kingdom. From policy 'taking' to policy 'shaping'. In: A. Jordan and D. Liefferink, eds. Environmental policy in Europe: the Europeanisation of national environmental policy. London: Routledge, 205-223.

Jordan, A., Bauer, M.W., and Green-Pedersen, C., 2013. Policy dismantling. Journal of European Public Policy, 20 (5), 795-805. doi:10.1080/13501763.2013.771092

Jordan, A. and Liefferink, D., 2004. The Europeanisation of national environmental policy. In: A. Jordan and D. Liefferink, eds. Environmental policy in Europe: the Europeanisation of national environmental policy. London: Routledge, 1-14.

Judge, D., ed., 1992. A green dimension for the European Community: political issues and processes. Environmental Politics (Special Issue), 1, 4.

Khan, S. 2017. Mayor of London Sadiq Khan's response to government air quality plan. Available from: https://www.london.gov.uk/press-releases/mayoral/ response-to-government-air-quality-plan [Accessed 1 January 2018].

Laville, S., Sauven, J., and Hogg, D. 2017. How do the four main parties compare on the environment? The Guardian, 21 May.

Lockwood, M., 2013. The political sustainability of climate policy: the case of the UK climate change act. Global Environmental Change, 23 (5), 1339-1348. doi:10.1016/j.gloenvcha.2013.07.001

Lorenzoni, I. and Benson, D., 2014. Radical institutional change in environmental governance: explaining the origins of the UK climate change act 2008 through discursive and streams perspectives. Global Environmental Change, 29, 10-21. doi:10.1016/j.gloenvcha.2014.07.011

Lowe, P. and Ward, S., eds., 1998. British environmental policy and Europe: politics and policy in transition. London: Routledge.

Merrick, R., 2017. Petrol-diesel car ban: government plan dismissed as 'smokescreen' after key air pollution policies dumped. The Independent, 26 July.

National Audit Office, December 2017. Implementing the UK's exit from the European Union, the department for environment, food \& rural affairs. Available from: https://www.nao.org.uk/wp-content/uploads/2017/12/ Implementing-the-UKs-exit-from-the-European-Union-the-Department-forEnvironment-Food-Rural-Affairs.pdf [Accessed 1 January 2018]. 
National Farmers' Union, 2017. NFU reaction to neonicotinoids announcement. Available from: https://www.nfuonline.com/cross-sector/environment/bees-andpollinators/bees-and-pollinators-news/nfu-reaction-to-neonicotinoidsannouncement/ [Accessed 30 October 2018].

Osborne, G., 2011. Autumn statement, 29 November 2011. Hansard, Vol. 536, Column 799. Available from: https://hansard.parliament.uk/Commons/2011-1129/debates/11112951000009/AutumnStatement?highlight=autumn\%20state ment\#contribution-11112951000260. [Accessed 30 October 2018].

Owen, J., Llyod, L., and Rutter, J., 18 June 2018. Preparing Brexit, how ready is Whitehall? Institute for Government. Available from: https://www.instituteforgo vernment.org.uk/sites/default/files/publications/IFGJ6279-Preparing-Brexit-

Whitehall-Report-180607-FINAL-3c.pdf [Accessed 1 July 2018].

Petetin, L., 2018. International obligations and devolved powers - ploughing through competences and GM crops. Environmental Law Review, 20 (1), 16-31. doi:10.1177/1461452918759639

Raagmaa, G., Kalvet, T., and Kasesalu, R., 2014. Europeanisation and de-Europeanisation of Estonian regional policy. European Planning Studies, 22 (4), 775-795. doi:10.1080/09654313.2013.772754

Radaelli, C., 2004. Europeanisation: solution or problem? European Integration OnLine Papers, 8 (16). Available from: http://eiop.or.at/eiop/texte/2004-016a.htm [Accessed 1 January 2017].

Reid, C., 2015. Written evidence to the environment audit committee's assessment of EU-UK environmental policy. Available from: http://data.parliament.uk/writtene vidence/committeeevidence.svc/evidencedocument/environmental-auditcommittee/assessment-of-euuk-environmental-policy/written/24036.pdf [Accessed 31 December 2016].

Reid, C., 2016. Brexit and the future of UK environmental law. Journal of Energy and Natural Resources Law, 34 (4), 407-415. doi:10.1080/02646811.2016.1218133

Roger, A., 2016. Written evidence. Submitted to house of commons environmental audit committee inquiry on the future of chemicals regulation after the EU referendum. Available from: http://data.parliament.uk/WrittenEvidence/ CommitteeEvidence.svc/EvidenceDocument/Environmental\%20Audit/EU\% 20Chemicals\%20Regulation/written/45853.html [Accessed 1 June 2017].

Royles, E. and McEwen, N., 2015. Empowered for action? Capacities and constraints in sub-state government climate action in Scotland and Wales. Environmental Politics, 24 (6), 1034-1054. doi:10.1080/09644016.2015.1053726

Savage, M., 2017. Big business leaders press Theresa May to rethink hard Brexit. The Observer, 18 June.

Scottish Government., 2018. Returning EU powers. Available from: https://news.gov. scot/news/returning-eu-powers [Accessed 1 January 2018].

Simkins, G., 2017. Brexit 'could threaten' microbeads ban. The ENDS Report. Available from: http://www.endsreport.com/article/56595/brexit-could-threatenmicrobeads-ban?printFriendly=true [Accessed 18 June 2017].

Slominski, P., 2016. Energy and climate policy: does the competitiveness narrative prevail in times of crisis? Journal of European Integration, 38 (3), 343-357. doi:10.1080/07036337.2016.1140759

Steffani, S. and Cooper, C., 2018. The green washing of Theresa May. Politico. Available from: https://www.politico.eu/article/the-greenwashing-of-theresa-may /. [Accessed 10 January 2018]. 
Steinebach, Y. and Knill, C., 2017. Still an entrepreneur? The changing role of the European Commission in EU environmental policy-making. Journal of European Public Policy, 24 (3), 429-446. doi:10.1080/13501763.2016.1149207

Stern, N., 2006. The economics of climate change. The Stern review. Cambridge: Cambridge University Press.

Vasilopoulou, S., 2015. Mixed feelings: Britain's conflicted attitudes to the EU before the referendum. Policy Network Paper. Available from: http://www.policynetwork.net/publications_detail.aspx?ID=4964 [Accessed 18 June 2016].

Weale, A., et al., 2000. European environmental governance. Oxford: Oxford University Press.

Wurzel, R., 2006. Environmental policy-making in Britain, Germany and the European Union. Manchester: Manchester University Press.

YouGov. August 2016. YouGov survey Brexit environment. Available from: https:// www.foe.co.uk/sites/default/files/downloads/yougov-survey-brexit-environmentaugust-2016-101683.pdf [Accessed 26 Febuary 2018].

Zito, A.R., Burns, C., and Lenschow, A., 2019. Is the trajectory of European Union environmental policy less certain? Environmental Politics, 28 (2). 